\title{
Analisis Pengaruh Alokasi DAK Masing-Masing Bidang Terhadap Tingkat Kemiskinan di Kabupaten Pandeglang dan Kabupaten Lebak
}

\author{
Analysis of the Effect of Spesific Allocation Fund for Each Sector on Poverty \\ Levels in Pandeglang and Lebak Regency
}

\author{
Asti Yayuk Wahyuni ${ }^{1}$ \\ Dinas Tanaman Pangan dan Hortikultura Kabupaten Bogor, Kabupaten Bogor, Indonesia
}

\section{Bambang Juanda}

Program Studi IImu Perencanaan Pembangunan Wilayah dan Perdesaan

Fakultas Ekonomi dan Manajemen, Institut Pertanian Bogor, Bogor, Indonesia

\section{Yeti Lis Purnamadewi}

Program Studi IImu Perencanaan Pembangunan Wilayah dan Perdesaan

Fakultas Ekonomi dan Manajemen, Institut Pertanian Bogor, Bogor, Indonesia

Artikel Masuk : 16 Juli 2020

Artikel Diterima : 5 Februari 2021

Tersedia Online : 30 April 2021

\begin{abstract}
Abstrak: Desentralisasi fiskal adalah salah satu upaya pemerintah dalam rangka mencapai tujuan peningkatan kesejahteraan masyarakat. Instrumen kebijakan desentralisasi fiskal yang secara langsung dapat memengaruhi kualitas belanja pemerintah daerah adalah Dana Alokasi Khusus (DAK). Permasalahan utama pengelolaan DAK dalam aspek keuangan adalah belum optimalnya kinerja DAK bagi daerah karena ketidaksesuaian antara besaran alokasi dengan kebutuhan daerah. Pengalokasian DAK berbasis proposal diharapkan dapat disesuaikan dengan prioritas pembangunan dengan kondisi dan kebutuhan daerah serta mengalokasikan DAK ke daerah/desa-desa tertinggal atau desa-desa dengan tingkat kemiskinan yang masih tinggi. Kabupaten Pandeglang dan Lebak adalah kabupaten dengan tingkat kemiskinan tertinggi di Provinsi Banten. Berdasarkan hal tersebut, maka penelitian ini bertujuan untuk menganalisis pengaruh alokasi DAK masing-masing bidang terhadap tingkat kemiskinan khususnya di Kabupaten Pandeglang dan Lebak. Metode yang digunakan dalam penelitian ini adalah geographically weighted regression (GWR) dengan menggunakan data DAK masingmasing bidang pada tahun 2018 dan data kemiskinan tahun 2019. Berdasarkan hasil analisis, variabel DAK bidang pendidikan, bidang kesehatan dan keluarga berencana dan bidang pertanian menunjukkan kecenderungan tidak menurunkan angka kemiskinan. Variabel DAK bidang perumahan dan permukiman, bidang kelautan dan perikanan, bidang pariwisata dan bidang pasar menunjukkan kecenderungan menurunkan tingkat kemiskinan. Sedangkan variabel DAK bidang Jalan, bidang sanitasi dan Dana desa cenderung menurunkan tingkat kemiskinan di sebagian besar kecamatan. Berdasarkan hal tersebut, maka program
\end{abstract}

\footnotetext{
${ }^{1}$ Korespondensi Penulis: Dinas Tanaman Pangan dan Hortikultura Kabupaten Bogor, Kabupaten Bogor, Indonesia Email: asyoeni@gmail.com
} 


\title{
2 Analisis Pengaruh Alokasi DAK Masing-Masing Bidang Terhadap Tingkat Kemiskinan ...
}

pengentasan kemiskinan di tiap kecamatan disesuaikan dengan masing-masing bidang dari DAK yang berpengaruh.

Kata Kunci: DAK; daerah tertinggal; GWR; kemiskinan

\begin{abstract}
Fiscal decentralization is one of the government's strategies to improve people's welfare. The fiscal decentralization policy instrument that can directly affect the quality of local government spending is The Specific Allocation Fund (DAK). The DAK management in the financial aspect has a few problems, nonoptimal regional government performance and mismatched allocation and government needs. Proposal based The Specific Allocation Fund (DAK) hopefully could adjust the development priorities determined by regional conditions, government needs, and undeveloped villages with high-level poverty. Pandeglang and Lebak Regency are the region with the highest poverty level in Banten Province. This study aims to analyze the DAK effect of each sector on poverty in Pandeglang and Lebak Regency. The analysis used Geographical Weighted Regression (GWR) with DAK data for each field in 2018 and poverty data in 2019. The result showed that DAK variables in education, health, and agriculture tended not to reduce poverty rates. The DAK variable in the housing and settlement sector, the marine and fisheries sector, the tourism sector, and the market sector tended to reduce poverty. At the same time, the DAK variable in Road, sanitation, and village funds tended to reduce poverty levels in most districts. Based on the study, the poverty alleviation program in each district is adjusted to each of the DAK sectors that are influential. However, the result indicated that the adjustment of DAK sectors influenced the poverty alleviation program in every district in Pandeglang and Lebak Regency.
\end{abstract}

Keywords: GWR; poverty; the specific allocation fund (DAK); undeveloped villages

\section{Pendahuluan}

Pemerintah Indonesia memberikan otonomi kepada daerah dalam menyelenggarakan pemerintahannya untuk meningkatkan kesejahteraan masyarakat, pelayanan umum dan daya saing daerah, sesuai dengan Undang - Undang (UU) Nomor 23. Tahun 2014 tentang Pemerintahan Daerah. Adanya otonomi, maka desentralisasi merupakan konsekuensi dari penyerahan wewenang yang disertai dengan pelimpahan wewenang dalam penggunaan anggaran untuk melaksanakan wewenang tersebut. Titik berat dari desentralisasi fiskal adalah desentralisasi dari sisi belanja yaitu pelimpahan kewenangan dan tanggung jawab oleh pemerintah pusat kepada pemerintah daerah menyangkut sumber-sumber penerimaan dan kewajiban pengeluaran seperti diatur dalam UU Nomor 33 Tahun 2004 tentang Perimbangan Keuangan antara Pemerintahan Pusat dan Daerah. Dana Perimbangan merupakan pendanaan daerah yang bersumber dari Anggaran Pendapatan dan Belanja Negara (APBN) yang terdiri atas Dana Bagi Hasil (DBH), Dana Alokasi Umum (DAU), dan Dana Alokasi Khusus (DAK).

Instrumen kebijakan desentralisasi fiskal yang secara langsung dapat memengaruhi kualitas belanja pemerintah daerah adalah DAK. Hal tersebut karena DAK memiliki sifat yang sangat spesifik (specific grant) yang berarti DAK dialokasikan kepada daerah tertentu untuk membiayai kebutuhan khusus dengan memperhatikan ketersediaan dana dalam APBN. Tujuan DAK adalah membantu daerah tertentu untuk mendanai kebutuhan sarana dan prasarana pelayanan dasar masyarakat dan untuk mendorong percepatan pembangunan daerah dan pencapaian sasaran prioritas nasional.

Berdasarkan hasil kajian yang dilakukan oleh Badan Perencanaan Pembangunan Nasional (Bappenas) permasalahan utama pengelolaan DAK dalam aspek keuangan adalah belum optimalnya kinerja DAK bagi daerah karena ketidaksesuaian (mismatch) antara besaran alokasi dengan kebutuhan daerah (Bappenas, 2011). Dalam aspek teknis, terdapat 
permasalahan yang berkaitan dengan masih belum optimalnya kebijakan teknis DAK. Dalam aspek kelembagaan, terdapat permasalahan yang berkaitan dengan belum mantap dan optimalnya koordinasi kelembagaan antara pusat dan daerah, belum terbentuknya tim koordinasi di pusat dan provinsi, serta belum optimalnya kinerja tim koordinasi di Kabupaten/Kota. Dalam aspek tata kepemerintahan yang baik (good governance) terdapat permasalahan yang berkaitan dengan masih rendahnya kinerja penerapan prinsip transparansi, akuntabilitas, dan partisipasi dalam pengelolaan DAK. Penyediaan data dan informasi teknis yang diperlukan dalam perhitungan alokasi DAK juga masih lemah.

Permasalahan-permasalahan tersebut menjadi bahan evaluasi bagi pemerintah, sehingga mulai tahun anggaran 2016 pemerintah mengalokasikan DAK disempurnakan dengan berbasis proposal (proposal based). DAK berbasis proposal ini dialokasikan agar pemerintah daerah dapat melakukan penyusunan proposal yang disesuaikan dengan prioritas pembangunan, dengan kondisi dan kebutuhan daerah serta mengalokasikan DAK ke daerah/desa-desa tertinggal atau desa-desa dengan tingkat kemiskinan yang masih tinggi, sehingga dapat mendorong pertumbuhan ekonomi desa-desa tersebut serta mengurangi ketimpangan. Jika alokasi DAK berbasis proposal ini diterapkan sesuai prosedur operasi bakunya, maka diharapkan akan mendorong pertumbuhan ekonomi dan juga dapat mengurangi ketimpangan pembangunan antardaerah jika pemerintah pusat memprioritaskan daerah-daerah yang infrastrukturnya masih kurang memadai (Juanda \& Handra, 2017).

Berdasarkan alokasi DAK dari tahun 2017-2019, Kabupaten Pandeglang dan Lebak termasuk kabupaten yang mendapatkan alokasi DAK terbesar. Pada tahun 2018, Kabupaten Pandeglang dan Kabupaten Lebak merupakan kabupaten dengan tingkat kemiskinan tertinggi dibandingkan dengan kabupaten/kota lain di Provinsi Banten dengan persentase jumlah penduduk miskin sebesar 9,61\% dan 8,41\%. Nilai tersebut berbeda jauh dengan Kota Tangerang Selatan dengan persentase penduduk miskin sebesar 1,68\%. Begitu pun pada tahun-tahun sebelumnya, sehingga Kabupaten Pandeglang dan Kabupaten Lebak harus menjadi perhatian khusus bagi pemerintah Provinsi maupun pemerintah pusat mengingat kedua kabupaten tersebut menjadi salah satu kabupaten dengan kategori daerah tertinggal. Hasil penelitian Panji \& Indrajaya (2016) menunjukkan bahwa DAK berpengaruh secara tidak langsung terhadap tingkat kemiskinan melalui pertumbuhan ekonomi di Provinsi Bali. Begitu pun hasil penelitian Qomariyah et al. (2017) yang merekomendasikan bahwa pemerintah pusat hendaknya meningkatkan injeksi dana langsung ke daerah melalui DAK bidang infrastruktur karena dampaknya efektif menurunkan kemiskinan.

Kebaruan (novelty) dari penelitian ini adalah penelitian ini menganalisis pengaruh dana alokasi khusus (DAK) masing-masing bidang dalam penelitian ini menggunakan sepuluh bidang DAK terhadap kemiskinan secara spasial yang belum dilaksanakan pada penelitian sebelumnya. Pada penelitian sebelumnya Qomariyah et al. (2017) hanya melihat pengaruh DAK bidang jalan dan irigasi terhadap kemiskinan dan belum memasukkan bidang lainnya. Begitu pula penelitian Panji and Indrajaya (2016) serta Jolianis (2016) melihat pengaruh DAK secara keseluruhan terhadap tingkat kemiskinan. Penelitian ini memetakan pengaruh DAK masing-masing bidang secara spasial sehingga dapat dilihat pengaruh dari setiap variabel bidang terhadap kemiskinan pada setiap daerah khususnya tingkat kecamatan. Berdasarkan hal tersebut, maka penelitian ini bertujuan untuk menganalisis pengaruh alokasi DAK masing-masing bidang terhadap tingkat kemiskinan khususnya di Kabupaten Pandeglang dan Lebak. 


\section{Analisis Pengaruh Alokasi DAK Masing-Masing Bidang Terhadap Tingkat Kemiskinan ...}

\section{Metode Penelitian}

\section{Metode Pengumpulan Data}

Data yang digunakan dalam penelitian ini adalah data sekunder. Pengumpulan data sekunder dilakukan dengan cara studi literatur dari berbagai dokumen di beberapa instansi terkait dan hasil-hasil penelitian sebelumnya seperti hasil penelitian Panji and Indrajaya (2016) dan Jolianis (2016) yang menggunakan data DAK secara total serta Qomariyah et al. (2017) yang menggunakan data DAK bidang jalan dan bidang irigasi. Data yang digunakan adalah data dari realisasi keuangan anggaran DAK bidang pendidikan, bidang kesehatan dan keluarga berencana, bidang perumahan dan permukiman, bidang pertanian, bidang kelautan dan perikanan, bidang pariwisata, bidang jalan, bidang air minum, bidang sanitasi dan bidang pasar. Selain data DAK masing-masing bidang, penelitian ini juga menggunakan variabel dana desa, kepadatan penduduk serta persentase penduduk miskin sebagai variabel dependent. Periode data yang digunakan adalah data tahun 2018 dan data tahun 2019 pada variabel yang diteliti.

\section{Metode Analisis Data}

Metode analisis yang digunakan adalah Geographical Weight Regression (GWR) yang merupakan pengembangan dari model regresi linier untuk memodelkan data dengan variabel respon yang mempertimbangkan aspek data spasial atau lokasi. Model GWR adalah suatu model regresi global yang diubah menjadi regresi yang terboboti. Model ini lebih mempertimbangkan faktor lokasi dan merupakan model regresi linier lokal yang menghasilkan penduga parameter model yang bersifat lokal dalam setiap pengamatannya (Fotheringham et al., 2002). Adapun variabel prediktor pada GWR masing-masing koefisien regresi bergantung pada lokasi data diamati sesuai dengan titik koordinat. Model GWR merupakan metode statistika yang umumnya digunakan untuk analisis heterogenitas spasial, yaitu apabila satu variabel bebas yang sama memberikan respon yang tidak sama pada lokasi yang berbeda dalam satu wilayah yang akan diteliti. Hasilnya yaitu suatu penaksir parameter model yang bersifat lokal untuk setiap titik atau lokasi data tersebut diamati.

Secara umum model GWR dirumuskan seperti persamaan (1).

$$
Y_{i}=\beta_{0}\left(u_{i}, \mathrm{v}_{i}\right)+\sum_{k=1} \beta_{k}\left(u_{i}, \mathrm{v}_{i}\right) X_{i k}+\varepsilon_{i}
$$

Keterangan: $\mathrm{Yi}=$ nilai Observasi variabel respon ke-i; Xik= nilai observasi prediktor $\mathrm{k}$ pada pengamatan ke-i; $\beta 0=$ intercept; $\beta \mathrm{k}=$ koefisien regresi; (ui,vi) $=$ titik koordinat spasial (lintang bujur) untuk pengamatan ke-i; $\varepsilon \mathrm{i}=$ error ke-i.

Penelitian ini akan melihat pengaruh penggunaan DAK masing-masing bidang terhadap kemiskinan. Variabel dependen yang digunakan adalah persentase kemiskinan tahun 2019, sementara variabel independen yang digunakan adalah variabel DAK masingmasing bidang serta variabel lain tahun 2018 yang diduga memengaruhi kemiskinan di Kabupaten Lebak dan Pandeglang. Adapun faktor lain terdiri dari dana desa dan kepadatan penduduk. Adapun tujuan model GWR yang digunakan adalah untuk mengetahui keragaman spasial pengaruh DAK masing-masing bidang terhadap kemiskinan seperti yang ditampilkan pada persamaan (2).

$$
\begin{aligned}
\text { Kemiskinan }_{\text {it }}= & \mathrm{b}_{0} \text { (ui,vi) }+\mathrm{b}_{1} \text { (ui,vi) } \mathrm{X}_{1 \mathrm{it}-1}+\mathrm{b}_{2} \text { (ui,vi) } \mathrm{X}_{2 \mathrm{it}-1}+\mathrm{b}_{3} \text { (ui,vi) } \mathrm{X}_{3 \mathrm{it}-1}+\mathrm{b}_{4} \\
& \text { (ui,vi) } \mathrm{X}_{4 \mathrm{it}-1}+\mathrm{b}_{5} \text { (ui,vi) } \mathrm{X}_{5 \mathrm{it}-1}+\mathrm{b}_{6} \text { (ui,vi) } \mathrm{X}_{6 \mathrm{it}-1}+\mathrm{b}_{7} \text { (ui,vi) } \mathrm{X}_{7 \mathrm{it}-1}+\mathrm{b}_{8} \\
& \left(\text { ui,vi) } \mathrm{X}_{8 \mathrm{it}-1}+\mathrm{b}_{9}\left(\text { ui,vi) } \mathrm{X}_{9 \mathrm{it}-1}+\mathrm{b}_{10} \text { (ui,vi) } \mathrm{X}_{10 \mathrm{it}-1}+\mathrm{b}_{11} \text { (ui,vi) } \mathrm{X}_{11 \mathrm{it}-1}\right.\right. \\
& +\mathrm{b}_{12}(\text { ui,vi }) \mathrm{X}_{12 \mathrm{it}-1}+\varepsilon_{\mathrm{i}}
\end{aligned}
$$


Keterangan: Kemiskinan ${ }_{i t=}$ persentase penduduk miskin setiap kecamatan ke-i (\%) tahun t; $\mathrm{X}_{1 \mathrm{it}-1}=\mathrm{DAK}$ bidang pendidikan per kapita pada kecamatan ke-i tahun $\mathrm{t}-1 ; \mathrm{X}_{2 \mathrm{it}-1}=\mathrm{DAK}$ bidang kesehatan dan keluarga berencana per kapita pada kecamatan ke-i tahun $\mathrm{t}-1 ; \mathrm{X}_{3 \mathrm{it}-1}=$ DAK bidang perumahan dan permukiman per kapita pada kecamatan ke-i tahun $\mathrm{t}-1 ; \mathrm{X}_{4 i \mathrm{t}-1}=$ DAK bidang pertanian per kapita pada kecamatan ke-I tahun $\mathrm{t}-1 ; \mathrm{X}_{5 \mathrm{it}-1}=$ DAK bidang kelautan dan perikanan per kapita pada kecamatan ke-i tahun $\mathrm{t}-1$; $\mathrm{X}_{6 \mathrm{it}-1}=\mathrm{DAK}$ bidang pariwisata per kapita pada kecamatan ke-i tahun t-1; $\mathrm{X}_{7 \mathrm{it}-1}=\mathrm{DAK}$ bidang jalan per kapita pada kecamatan ke-i tahun $\mathrm{t}-1 ; \mathrm{X}_{8 \mathrm{it}-1}=\mathrm{DAK}$ bidang air minum per kapita pada kecamatan ke-i tahun $\mathrm{t}-1 ; \mathrm{X}_{9 \mathrm{it}-1}=\mathrm{DAK}$ bidang sanitasi per kapita pada kecamatan ke-i tahun $\mathrm{t}-1 ; \mathrm{X}_{10 \mathrm{it}-1}=$ DAK bidang pasar per kapita pada kecamatan ke-i tahun t-1; $\mathrm{X}_{11 \text { it-1 }}=$ Jumlah Dana Desa per kapita pada kecamatan ke-i tahun t-1; $\mathrm{X}_{12 \mathrm{it}-1}=$ Kepadatan penduduk pada kecamatan ke-i tahun $\mathrm{t}-1$.

Selanjutnya pengujian parameter, yaitu untuk setiap variabel $\mathrm{X}$ yang digunakan dalam GWR, dilakukan uji signifikansi untuk melihat adanya pengaruh masing-masing variabel terhadap kemiskinan di Kabupaten Lebak dan Pandeglang secara spesifik lokasi. Uji signifikansi dilakukan terhadap masing-masing variablel pada setiap desa dengan taraf nyata lima persen $(0,05)$ dan sepuluh persen $(0,1)$. Setelah dilaksanakan pengolahan data, maka langkah selanjutnya adalah melakukan pemetaan hasil GWR. Pemetaan tersebut menggunakan parameter hasil yang berbeda-beda untuk memvisualisasikan hasil analisis spasial.

\section{Hasil dan Pembahasan}

Hasil estimasi GWR menunjukkan bahwa koefisien determinasi $\left(\mathrm{R}^{2}\right)$ berkisar antara 0,3683-0,5538. Dalam penelitian ini berarti variasi tingkat kemiskinan di Kabupaten Lebak dan Pandeglang dapat dijelaskan oleh faktor DAK bidang pendidikan, bidang kesehatan dan keluarga berencana, bidang perumahan, bidang pertanian, bidang kelautan dan perikanan, bidang pariwisata, bidang jalan, bidang air minum, bidang sanitasi, bidang pasar, serta dana desa dan kepadatan penduduk sebesar 36,83-55,83\%, sedangkan selebihnya ditentukan oleh faktor lain yang belum dimasukkan ke dalam model penelitian ini (Gambar 1).

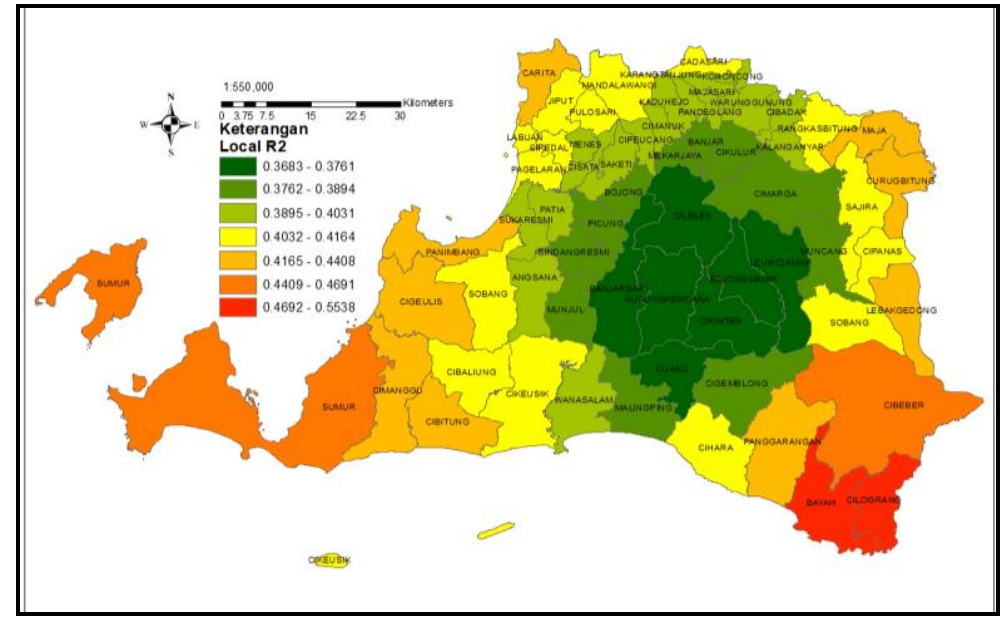

Gambar 1. Sebaran $\mathbf{R}^{2}$ Lokal untuk Setiap Kecamatan di Kabupaten Lebak dan Pandeglang 
6 Analisis Pengaruh Alokasi DAK Masing-Masing Bidang Terhadap Tingkat Kemiskinan ...

Tabel 1. Variasi Koefisien Parameter Hasil Estimasi GWR Kabupaten Lebak dan Pandeglang

\begin{tabular}{|c|c|c|c|c|c|c|c|}
\hline \multirow{3}{*}{ Parameter } & \multirow{2}{*}{\multicolumn{2}{|c|}{$\begin{array}{c}\text { Koefisien Parameter } \\
\text { GWR }\end{array}$}} & \multicolumn{4}{|c|}{ Koefisien Parameter GWR } & \multirow{3}{*}{$\begin{array}{c}\text { Jumlah } \\
\text { Kecamatan } \\
\text { yang } \\
\text { Signifikan }\end{array}$} \\
\hline & & & \multicolumn{2}{|c|}{ Uji Nyata 0,05} & \multicolumn{2}{|c|}{ Uji Nyata 0,1} & \\
\hline & Minimum & Maksimum & Minimum & Maksimum & Minimum & Maksimum & \\
\hline Intersep & $-0,2948$ & 0,4010 & $-0,2948$ & 0,4010 & $-0,2948$ & 0,4010 & 15 \\
\hline DAK Pendidikan & $-0,3302$ & 0,1899 & 0 & 0 & $-0,3302 *$ & $-0,2596 *$ & 2 \\
\hline $\begin{array}{l}\text { DAK Kesehatan } \\
\text { dan KB }\end{array}$ & 0,0493 & 0,2933 & 0,2933 & 0,2933 & 0,1864 & 0,2933 & 5 \\
\hline $\begin{array}{l}\text { DAK Perumahan } \\
\text { dan Permukiman }\end{array}$ & $-0,2580$ & $-0,0163$ & $-0,2580 *$ & $-0,2580^{*}$ & $-0,2580 *$ & $-0,2112 *$ & 13 \\
\hline DAK Pertanian & 0,0917 & 0,5817 & 0,2920 & 0,5817 & 0,2224 & 0,5817 & 19 \\
\hline $\begin{array}{l}\text { DAK Kelautan } \\
\text { dan Perikanan }\end{array}$ & $-0,6477$ & $-0,1027$ & $-0,6477 *$ & $-0,2942 *$ & $-0,6477 *$ & $-0,2503 *$ & 23 \\
\hline DAK Pariwisata & $-0,2158$ & $-0,1032$ & - & - & $-0,2158 *$ & $-0,1781 *$ & 10 \\
\hline DAK Jalan & $-0,0643$ & 0,2079 & - & - & - & - & 0 \\
\hline DAK Air Minum & $-0,1308$ & 0,1629 & - & - & - & - & 0 \\
\hline DAK Sanitasi & $-0,1490$ & 0,2227 & - & - & 0,2012 & 0,2227 & 2 \\
\hline DAK Pasar & $-0,2161$ & $-0,0828$ & $-0,2161 *$ & $-0,1967 *$ & $-0,2161 *$ & $-0,1674 *$ & 28 \\
\hline Dana Desa & $-0,2045$ & 0,0480 & - & - & - & - & 0 \\
\hline Kep. Penduduk & $-0,4927$ & $-0,2592$ & $-0,4927$ & $-0,3299$ & $-0,4927$ & $-0,2781$ & 62 \\
\hline
\end{tabular}

Keterangan * ${ }^{*}$ Sesuai dengan hipotesis penelitian

Setelah dilakukan uji signifikansi terhadap masing-masing koefisien parameter GWR dengan taraf nyata 0,05 dan 0,1 dapat dilihat dari dua belas variabel independent terdapat lima variabel yang sesuai dengan hipotesis penelitian. Variabel tersebut antara lain DAK bidang pendidikan, DAK bidang perumahan dan permukiman, DAK bidang kelautan dan perikanan, DAK bidang pariwisata dan DAK bidang pasar. Sedangkan, variabel yang belum sesuai dengan hipotesis penelitian adalah DAK bidang kesehatan dan keluarga berencana, DAK bidang pertanian, DAK bidang jalan, DAK bidang air minum, DAK bidang sanitasi, Dana Desa serta kepadatan penduduk. Hal tersebut terjadi karena koefisien untuk variabel anggaran bernilai positif serta koefisien untuk variabel kepadatan penduduk bernilai negatif. Nilai koefisien minimum dan maksimum dari masing-masing parameter berdasarkan hasil estimasi GWR dengan uji t dapat dilihat pada Tabel 1.

\section{Pengaruh DAK Bidang Pendidikan Terhadap Kemiskinan}

Berdasarkan dari hasil permodelan GWR untuk pengaruh DAK bidang pendidikan terhadap kemiskinan (Gambar 2a) dapat dilihat sebagian besar wilayah memiliki koefisien bertanda positif, yang berarti semakin besar anggaran DAK bidang pendidikan maka cenderung tidak menurunkan kemiskinan. Hal ini menunjukkan bahwa DAK bidang pendidikan masih kurang efektif menurunkan angka kemiskinan di sebagian besar wilayah Kabupaten Lebak dan Pandeglang. Akan tetapi, terdapat dua puluh wilayah yang memiliki koefisien bertanda negatif terutama di wilayah Kabupaten Lebak dan satu wilayah di Kabupaten Pandeglang.

Berdasarkan hasil uji signifikansi dapat diketahui bahwa dari 63 kecamatan di Kabupaten Lebak dan Pandeglang hanya dua kecamatan di Kabupaten Lebak yaitu Kecamatan Cilograng dan Cibeber yang berpengaruh nyata dalam mengurangi kemiskinan pada taraf nyata 0,1. Berdasarkan alokasi DAK bidang pendidikan, kedua kecamatan tersebut termasuk wilayah yang mendapatkan alokasi anggaran yang cukup besar. Besarnya alokasi DAK bidang pendidikan di wilayah tersebut serta hasil yang berpengaruh nyata terhadap penurunan angka kemiskinan, menunjukkan bahwa masih perlunya alokasi anggaran di bidang pendidikan di wilayah-wilayah lain, sehingga akan berpengaruh juga 
terhadap menurunnya angka kemiskinan di wilayah lain. Hal tersebut sesuai dengan hasil penelitian Martinez-Aguilar et al. (2017) yang menyatakan bahwa pengeluaran dalam bidang pendidikan akan menurunkan ketimpangan dan kemiskinan. Chen \& Wang (2015) menyatakan bahwa pendidikan menjadi salah satu faktor penting dalam pengentasan kemiskinan melalui perbaikan sumber daya manusia. Berdasarkan Gambar 2b dapat dilihat bahwa masih belum meratanya sebaran alokasi DAK bidang pendidikan terutama di kecamatan dengan persentase kemiskinan yang cukup tinggi. Menurut Jumiati et al. (2019), salah satu faktor penyebab kemiskinan di Kabupaten Pandeglang adalah rendahnya tingkat pendidikan, maka disarankan perlu adanya pengembangan sumber daya manusia terutama prioritas pada peningkatan pendidikan penduduk miskin.

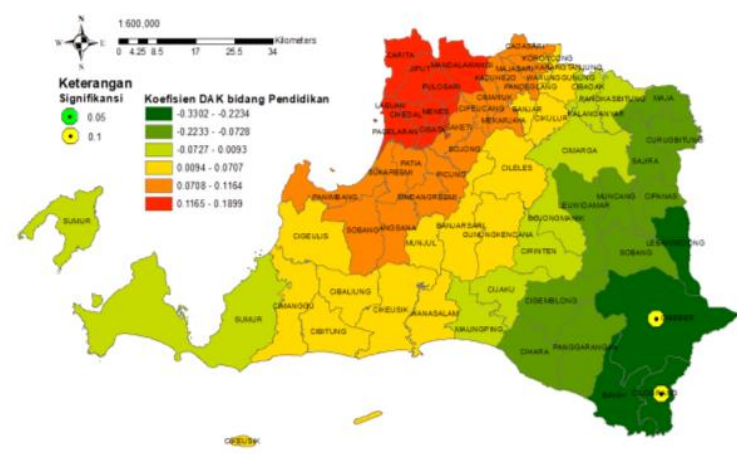

(a)

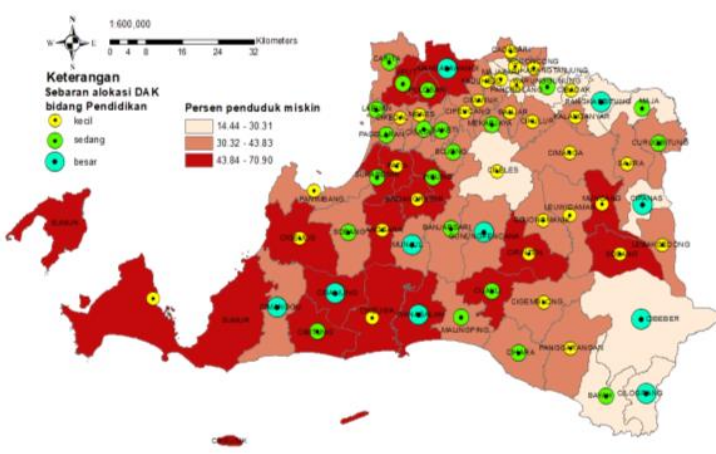

(b)

\section{Gambar 2. Pengaruh DAK Bidang Pendidikan terhadap Kemiskinan (a) Koefisien dan (b) Sebaran Alokasi DAK dan Persentase Penduduk Miskin}

\section{Pengaruh DAK Bidang Kesehatan Terhadap Kemiskinan}

Berdasarkan sebaran alokasi DAK bidang kesehatan, tidak semua kecamatan mendapatkan alokasi DAK tersebut. Bahkan perbedaan anggaran terbesar dan terkecil cukup signifikan, dengan anggaran terbesar adalah 5,492 miliar rupiah dan anggaran terkecil adalah 35 juta rupiah. Berdasarkan hasil permodelan GWR (Gambar 3) dapat dilihat bahwa DAK bidang kesehatan masih belum efektif dalam menurunkan kemiskinan. Hal tersebut dapat diketahui dengan koefisien positif di seluruh wilayah amatan. Wilayahwilayah yang mendapatkan alokasi DAK bidang kesehatan yang cukup besar justru menunjukkan hasil koefisien yang positif. Sedangkan, harapan dengan adanya alokasi anggaran kesehatan yang cukup besar dapat menurunkan angka kemiskinan. Hal ini juga menguatkan argumen bahwa signifikan dana transfer bukan tergantung pada besar kecilnya jumlah DAK, akan tetapi lebih kepada efisiennya pengalokasian serta efektifnya tata kelola implementasi DAK (Juanda et al, 2014).

Berdasarkan hasil uji signifikansi diperoleh bahwa lima kecamatan di Kabupaten Lebak signifikan DAK bidang kesehatan meningkatkan tingkat kemiskinan, sedangkan 58 menunjukkan hasil yang tidak signifikan. Hal tersebut memberikan kesimpulan bahwa naiknya tingkat kemiskinan di kedua kabupaten bukan disebabkan oleh besarnya alokasi anggaran DAK di bidang kesehatan akan tetapi oleh faktor lainnya. Belum efektifnya anggaran DAK di bidang kesehatan terhadap kemiskinan dapat disebabkan DAK bidang kesehatan dialokasikan untuk infrastruktur fisik seperti renovasi puskesmas, penyediaan alat kesehatan serta peralatan lainnya sehingga pengaruhnya terhadap peningkatan kualitas sumber daya manusia terlebih dahulu baru terhadap kemiskinan. Berdasarkan hasil penelitian Fan et al. (2004) yang menjelaskan bahwa belanja pemerintah di sektor 


\section{Analisis Pengaruh Alokasi DAK Masing-Masing Bidang Terhadap Tingkat Kemiskinan ...}

kesehatan tidak menunjukkan dampak besar pada pengurangan kemiskinan karena investasi kesehatan cenderung mempengaruhi pengurangan kemiskinan dalam jangka waktu yang lama.

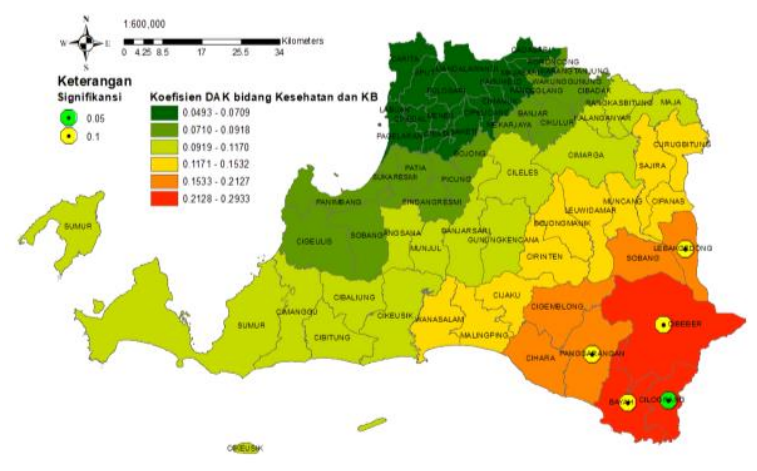

(a)

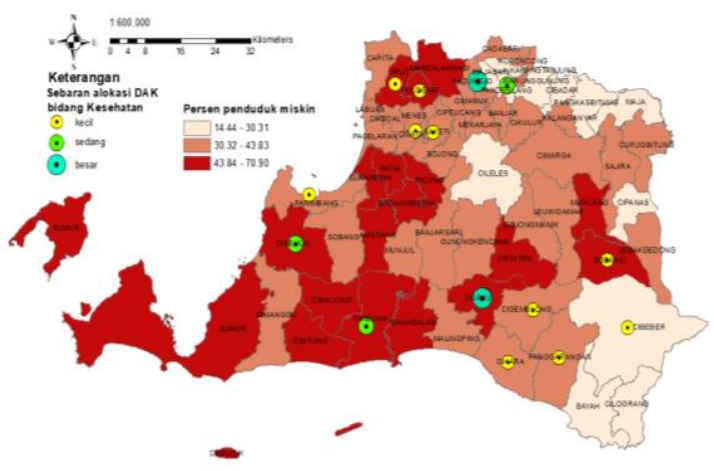

(b)

\section{Gambar 3. Pengaruh DAK Bidang Kesehatan dan Keluarga Berencana terhadap Kemiskinan (a) Koefisien dan (b) Sebaran Alokasi DAK dan Persentase Penduduk Miskin}

\section{Pengaruh DAK Bidang Perumahan dan Permukiman Terhadap Kemiskinan}

Hasil analisis terhadap koefisien GWR (Gambar 4) menunjukkan bahwa DAK bidang perumahan dan permukiman menunjukkan kecenderungan menurunkan kemiskinan di semua wilayah amatan serta berpengaruh nyata pada 13 kecamatan. Adapun nilai koefisien yang paling minimum sebesar 0,0163 yaitu Kecamatan Lebakgedong dan nilai maksimum sebesar 0,2580 yaitu Kecamatan Carita. Hasil ini sejalan dengan hasil penelitian Azwardi (2014) menunjukkan bahwa belanja fungsi kesehatan serta perumahan dan fasilitas umum berpengaruh nyata secara negatif terhadap jumlah penduduk miskin. Hal tersebut berarti jika pengeluaran/belanja pemerintah untuk fungsi tersebut ditingkatkan maka akan berdampak terhadap menurunnya angka kemiskinan. Begitu pula dengan penelitian yang dilakukan Syamsuri \& Bandiyono (2018) menunjukkan bahwa belanja pemerintah untuk fungsi pekerjaan umum dan perumahan rakyat menghasilkan hubungan yang negatif terhadap tingkat kemiskinan, akan tetapi hubungan ini tidak signifikan. Hasil penelitian menunjukkan bahwa setiap kenaikan $1 \%$ belanja PUPR, menyebabkan akan meningkatkan persentase masyarakat miskin sebesar 0,2523 , dengan asumsi ceteris paribus.

\section{Pengaruh DAK Bidang Pertanian Terhadap Kemiskinan}

Berdasarkan hasil analisis terhadap koefisien GWR (Gambar 5) menunjukkan bahwa DAK bidang pertanian cenderung tidak menurunkan kemiskinan di semua wilayah amatan. Hal tersebut dapat disebabkan bahwa alokasi DAK bidang pertanian dialokasikan untuk infrastruktur pertanian seperti jalan usaha tani, jaringan irigasi tingkat usaha tani yang tidak berdampak langsung terhadap kemiskinan akan tetapi baru berdampak terhadap peningkatan produksi, apabila peningkatan produksi tanpa dibarengi dengan akses pasar maka petani belum mendapatkan dampak langsung dari peningkatan produksi tersebut. Hal ini sejalan dengan dengan hasil penelitian Krisnawati et al. (2018) yang menunjukkan bahwa tidak adanya pengaruh dari peningkatan produksi padi baik terhadap kesejahteraan petani langsung maupun tingkat kemiskinan secara umum. Hasil ini tidak sejalan dengan hasil penelitian Hasanah \& Siregar (2014) yang menunjukkan bahwa anggaran belanja daerah untuk sektor pertanian memiliki pengaruh yang negatif dengan jumlah penduduk miskin baik secara total, di perdesaan dan perkotaan. Begitu pula dengan hasil penelitian 
Hermawan (2012), yang menunjukkan bahwa sektor pertanian berperan penting terhadap pengurangan kemiskinan di perdesaan dibandingkan perkotaan. Sektor pertanian menjadi kunci dan sebagai leading sector dalam mengurangi kemiskinan secara agregat, mengingat kemiskinan terbesar terdapat di perdesaan. Adapun masih belum menunjukkan pengaruh dalam penurunan angka kemiskinan, dapat disebabkan masih terbatasnya jumlah anggaran sehingga perlu bersinergi dengan anggaran dana desa terutama untuk sektor pertanian yang merupakan salah satu leading sector baik di Kabupaten Pandeglang maupun Kabupaten Lebak.

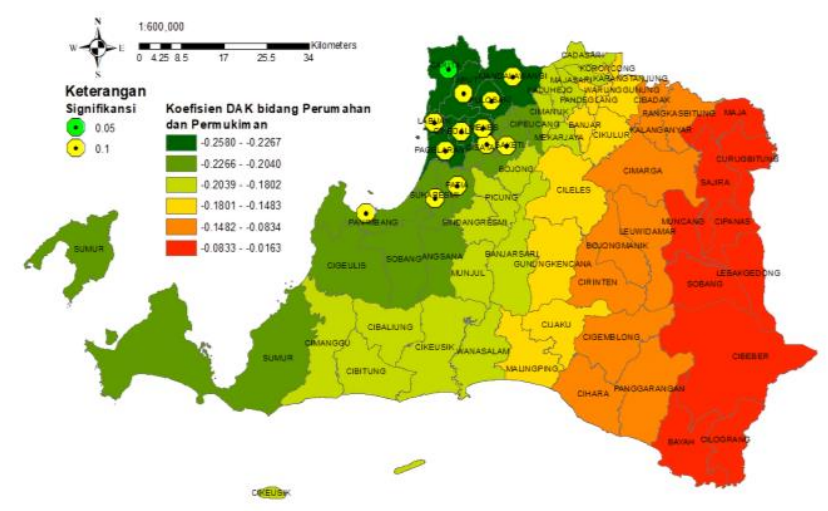

Gambar 4. Koefisien Pengaruh DAK Bidang Perumahan dan Permukiman terhadap Kemiskinan

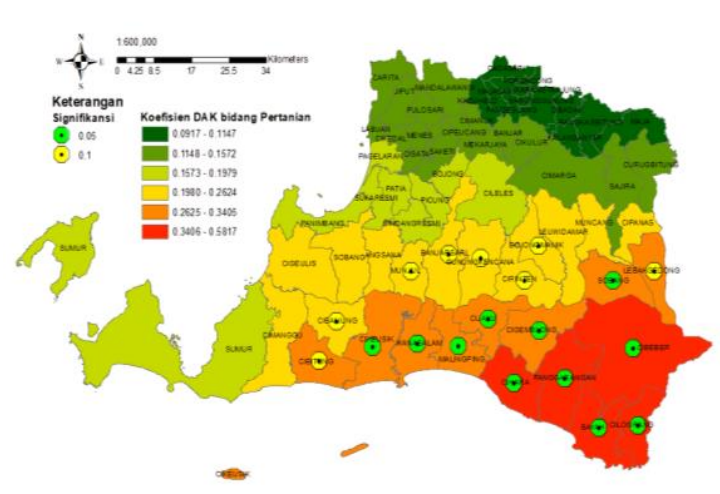

(a)

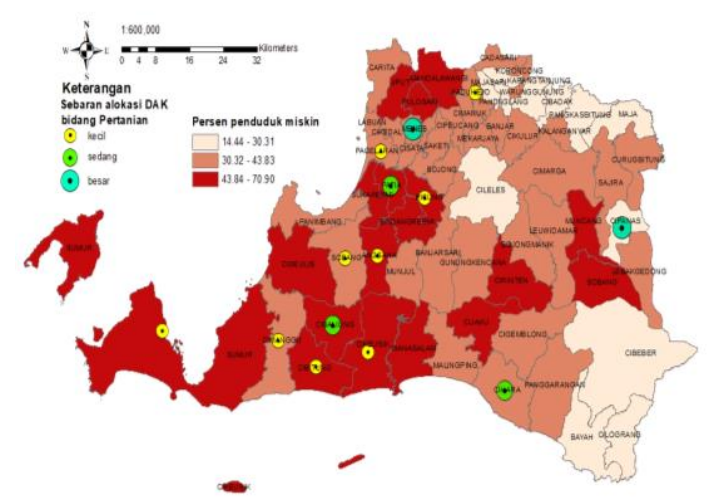

(b)

\section{Gambar 5. Pengaruh DAK Bidang Pertanian terhadap Kemiskinan (a) Koefisien dan (b) Sebaran Alokasi DAK dan Persentase Penduduk Miskin}

\section{Pengaruh DAK Bidang Kelautan dan Perikanan Terhadap Kemiskinan}

Hasil analisis terhadap koefisien GWR (Gambar 6) menunjukkan bahwa DAK bidang kelautan dan perikanan berpengaruh terhadap menurunkan kemiskinan di semua wilayah amatan serta signifikan di 24 kecamatan. Dari Gambar 6, dapat dilihat jika pengaruh yang cukup besar terdapat di daerah selatan (warna hijau) yang merupakan daerah yang berbatasan dengan Samudera Indonesia. Wilayah tersebut merupakan daerah berpantai dan merupakan wilayah dengan salah satu potensi yang dikembangkan merupakan perikanan. Adapun anggaran DAK bidang kelautan dan perikanan dialokasikan kepada Balai Benih Ikan (BBI), Tempat Pelelangan Ikan (TPI), Balai Budaya Ikan Air Tawar serta 
tempat pelestarian ikan berbasis pariwisata edukasi. Hal tersebut yang menyebabkan alokasi DAK bidang tersebut berdampak signifikan terhadap penurunan angka kemiskinan khususnya wilayah dengan potensi perikanan dan kelautan. Hasil yang menunjukkan pengaruh yang negatif terhadap kemiskinan sesuai dengan penelitian Djata (2018) yang menyatakan bahwa anggaran di bidang kelautan dan perikanan menunjukkan pengaruh yang signifikan dan efektif serta berkontribusi terhadap kesejahteraan masyarakat khususnya nelayan. Melihat pengaruh yang cukup baik terhadap penurunan kemiskinan, maka DAK bidang kelautan dan perikanan dinilai tepat sasaran karena pengalokasian sesuai dengan potensi lokasi.

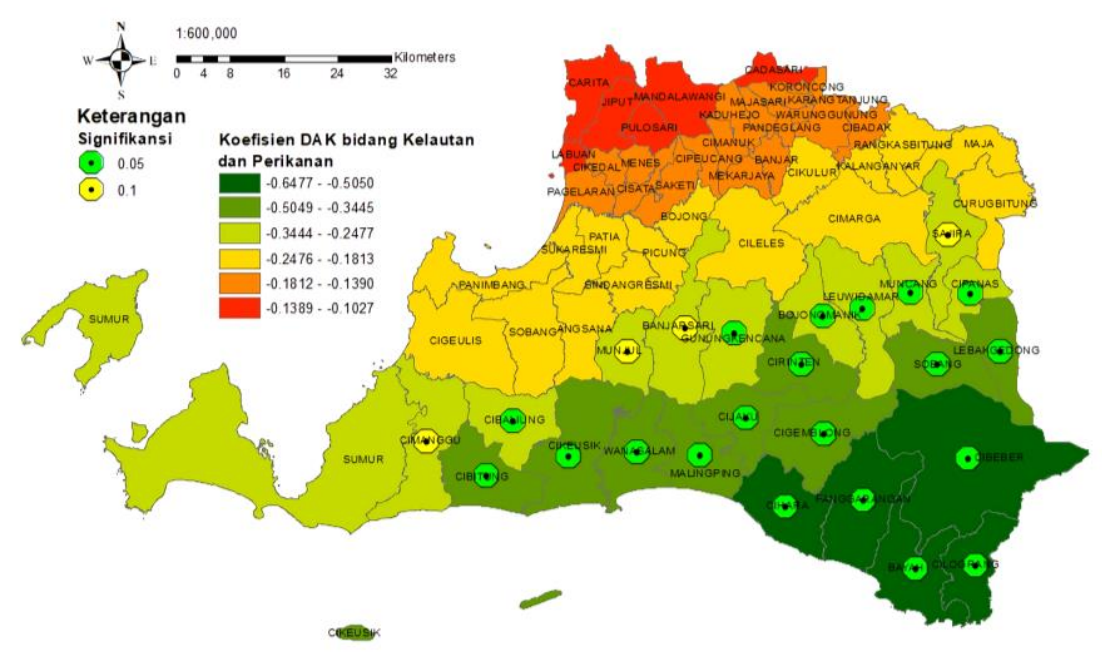

Gambar 6. Koefisien Pengaruh DAK Bidang Kelautan dan Perikanan terhadap Kemiskinan

\section{Pengaruh DAK Bidang Pariwisata Terhadap Kemiskinan}

Hasil analisis terhadap koefisien GWR (Gambar 7) menunjukkan bahwa DAK bidang pariwisata berpengaruh terhadap menurunkan kemiskinan di semua wilayah amatan serta signifkan di 10 kecamatan. Adapun nilai koefisien yang paling minimum sebesar 0,1032 yaitu Kecamatan Carita dan nilai maksimum sebesar 0,2158 yaitu Kecamatan Panggarangan. Nilai tersebut menunjukkan bahwa jika terjadi peningkatan alokasi DAK bidang pariwisata sebesar satu satuan maka akan menurunkan kemiskinan sebesar 0,1032 hingga 0,2158 satuan, ceteris paribus. Sejalan dengan hasil penelitian Herawati \& Ginting, (2019), yang menyatakan bahwa pengembangan pariwisata akan berdampak pada penciptaan lapangan kerja bagi masyarakat yang lebih luas dapat meningkatkan pendapatan masyarakat secara keseluruhan dan dapat meningkatkan kemakmuran rakyat.

Berdasarkan sebaran alokasi DAK bidang pariwisata baik di Kabupaten Lebak maupun Pandeglang, dapat diketahui bahwa ada 3 wilayah yang mendapatkan alokasi DAK bidang pariwisata yaitu Kecamatan Panimbang yang terletak di Kabupaten Pandeglang dan Kecamatan Bayah dan Leuwidamar yang terletak di Kabupaten Lebak. Kecamatan Panimbang Kabupaten Pandeglang menjadi wilayah dengan alokasi DAK bidang pariwisata yang cukup besar dikarenakan di wilayah tersebut terdapat destinasi wisata yang cukup terkenal yaitu Pantai Tanjung Lesung. Herawati \& Ginting (2019) menyatakan KEK Tanjung Lesung telah turut serta membangun perekonomian masyarakat sekitar karena telah meningkatkan jumlah wisatawan yang mendatangkan pemasukan bagi pengelola KEK dan juga masyarakat sekitar. Sedangkan dua wilayah di Kabupaten Lebak yaitu Kecamatan Bayah dan Leuwidamar mempunyai potensi wisata andalan yang diharapkan dapat 
meningkatkan PAD Kabupaten Lebak serta meningkatkan perekonomian di wilayah tersebut. Pengalokasian anggaran pada daerah dengan potensi wisata yang cukup tinggi, berdampak terhadap peningkatan aktivitas ekonomi di wilayah lain sehingga menghasilkan multiplier effect khususnya wilayah-wilayah di sekitar potensi wisata. Berdasarkan hal tersebut pengalokasian anggaran DAK bidang Pariwisata baik di Kabupaten Pandeglang dan Kabupaten Lebak dinilai sudah cukup tepat.

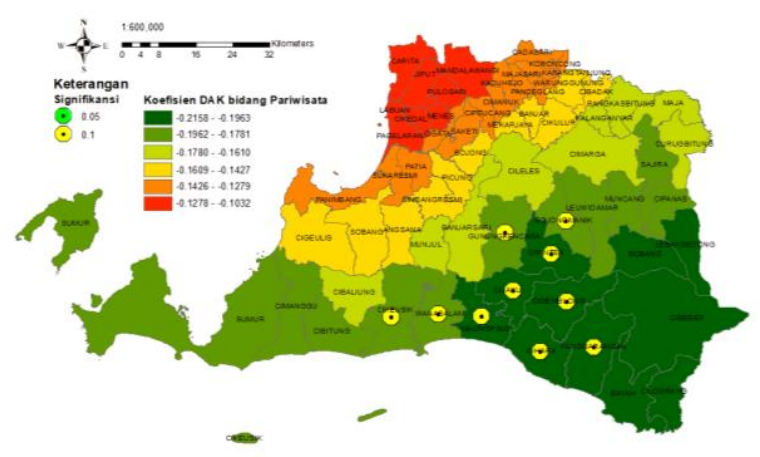

(a)

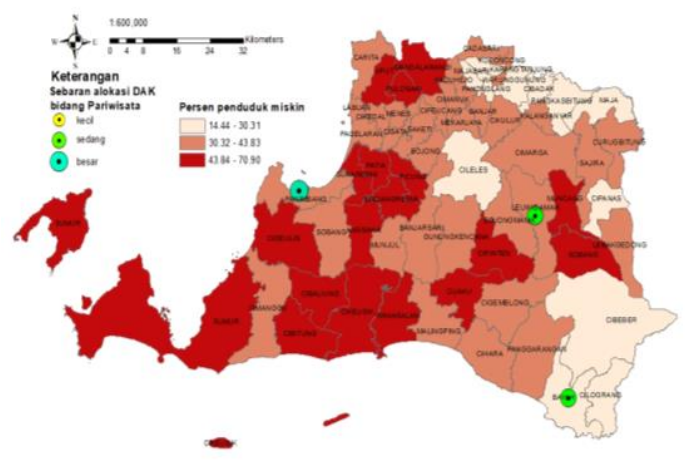

(b)

Gambar 7. Pengaruh DAK Bidang Pariwisata terhadap Kemiskinan (a) Koefisien dan (b) Sebaran Alokasi DAK dan Persentase Penduduk Miskin

\section{Pengaruh DAK Bidang Jalan Terhadap Kemiskinan}

Berdasarkan hasil analisis terhadap koefisien GWR (Gambar 8) sebagian besar wilayah amatan menunjukkan kecenderungan dalam menurunkan angka kemiskinan, yaitu pada 39 kecamatan (warna hijau sampai kuning tua), meskipun secara statistik belum menunjukkan pengaruh yang signifikan. DAK bidang jalan yang cenderung menurunkan angka kemiskinan menunjukkan semakin baiknya fasilitas infrastruktur terutama jalan akan mempermudah akses masyarakat terhadap pelayanan dasar sehingga akan berdampak terhadap kesejahteraan masyarakat itu pula. Berdasarkan hasil penelitian Sukanto et al. (2018), menyatakan bahwa keberadaan infrastruktur jalan cenderung menurunkan kemiskinan di 63 kecamatan yang tersebar di Kabupaten Lebak dan Pandeglang. Begitu pula dengan hasil penelitian Yudha et al. (2018) bahwa infrastruktur jalan merupakan infrastruktur yang paling berpengaruh dalam meningkatkan pertumbuhan ekonomi masyarakat desa yang akan berimbas pada menurunnya angka kemiskinan desa.

\section{Pengaruh DAK Bidang Air Minum Terhadap Kemiskinan}

DAK bidang air minum mempunyai tujuan untuk meningkatkan cakupan pelayanan air minum layak melalui penambahan jumlah sambungan rumah kepada rumah tangga diutamakan kelompok masyarakat bepenghasilan rendah. Hasil analisis terhadap koefisien GWR (Gambar 9a) menunjukkan bahwa DAK bidang air minum sebagian besar berpengaruh positif terhadap kemiskinan. Hal ini menunjukkan bahwa alokasi DAK bidang air minum belum menunjukkan kecenderungan dalam menurunkan angka kemiskinan. Hasil tersebut dapat disebabkan akses terhadap air layak minum tidak berdampak langsung terhadap kesejahteraan masyarakat, akan tetapi berpengaruh langsung terhadap kualitas sumber daya manusia. Setelah sumber daya manusia semakin berkualitas baru masyarakat mempunyai kemampuan untuk meningkatkan kesejahteraan mereka, atau dengan kata lain dampak dari anggaran bidang air minum dapat dilihat dalam jangka panjang. 


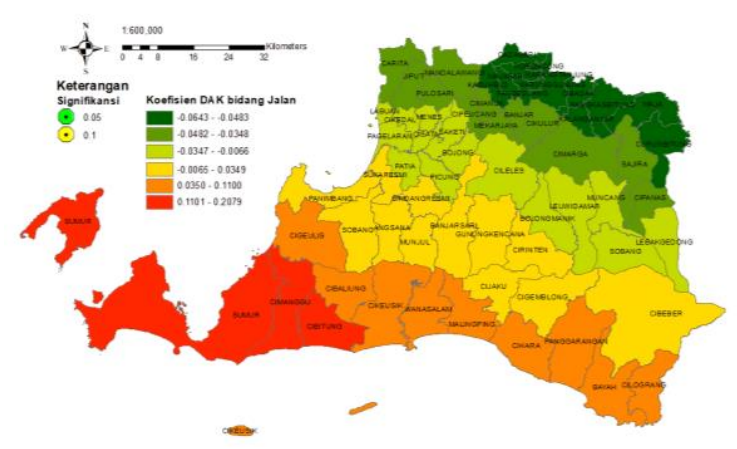

(a)

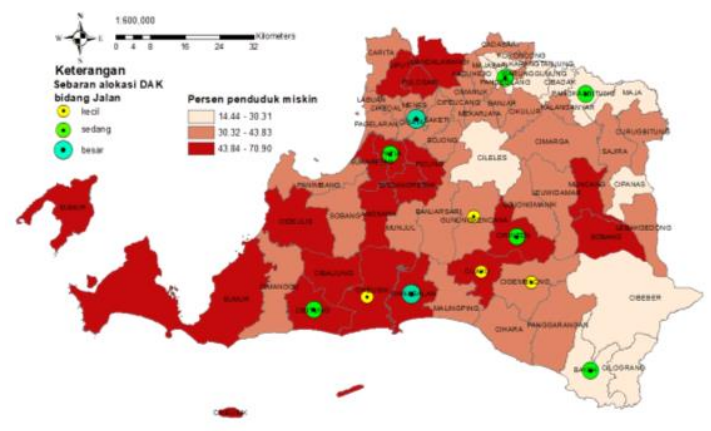

(b)

\section{Gambar 8. Pengaruh DAK Bidang Jalan terhadap Kemiskinan \\ (a) Koefisien dan (b) Sebaran Alokasi DAK dan Persentase Penduduk Miskin}

Berdasarkan nilai koefisien dan persentase kemiskinan dapat diketahui bahwa wilayah dengan tingkat kemiskinan yang cukup tinggi menunjukkan pengaruh yang bernilai egatif (menunjukkan kecenderungan menurunkan kemiskinan). Hal tersebut menunjukkan perlunya pengalokasian DAK bidang air minum terutama di wilayah yang merupakan kantong-kantong kemiskinan. Hasil tersebut sejalan dengan penelitian Sukanto et al. (2018) yang menunjukkan bahwa variabel air layak minum berpengaruh negatif terhadap kemiskinan. Berdasarkan sebaran alokasi DAK bidang air minum (Gambar 9b), beberapa kecamatan dengan tingkat kemiskinan yang rendah justru mendapatkan alokasi DAK yang cukup besar seperti Kecamatan Bayah, Cibeber, Cihara dan Labuan. Begitupun sebaliknya terdapat kecamatan dengan tingkat kemiskinan tinggi justru tidak mendapatkan alokasi DAK. Kondisi tersebut menunjukkan masih kurang tepatnya dalam pengalokasian anggaran sehingga perlu adanya evaluasi terutama dalam penentuan lokasi/wilayah yang akan mendapatkan alokasi anggaran DAK bidang tersebut.

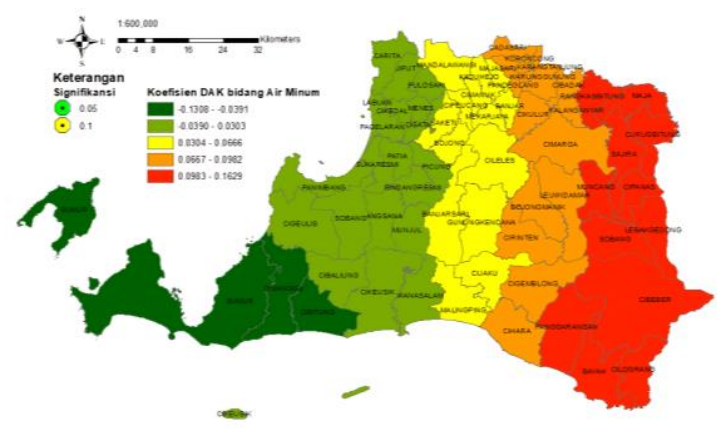

(a)

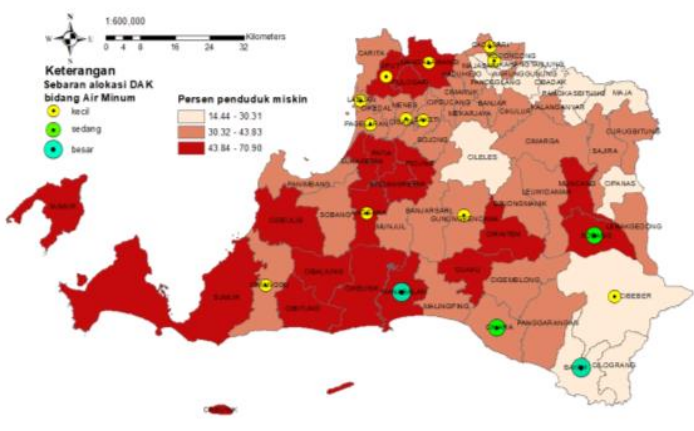

(b)

Gambar 9. Pengaruh DAK Bidang Air Minum terhadap Kemiskinan (a) Koefisien dan (b) Sebaran Alokasi DAK dan Persentase Penduduk Miskin

\section{Pengaruh DAK Bidang Sanitasi Terhadap Kemiskinan}

Salah satu faktor penyebab kemiskinan adalah terbatasnya akses terhadap pelayanan dasar, terutama kesehatan, pendidikan, perumahan, air bersih, sanitasi dan infrastruktur dasar. Maka dengan adanya DAK bidang sanitasi diharapkan dapat menjadi salah satu faktor pendorong dalam menurunkan angka kemiskinan. Berdasarkan hasil analisis 
terhadap koefisien GWR (Gambar 10), dapat diketahui bahwa DAK bidang sanitasi menunjukkan kecenderungan dalam menurunkan angka kemiskinan pada 37 kecamatan terutama wilayah Kabupaten Pandeglang, meskipun secara statistik belum menunjukkan pengaruh yang signifikan. Hasil penelitian ini sejalan dengan hasil penelitian Sukanto et al. (2018) bahwa variabel air bersih memiliki kecenderungan menurunkan tingkat kemiskinan di 36 kecamatan di Kabupaten Lebak dan Pandeglang. Berdasarkan hasil penelitian Lenz et al. (2015) yang menyatakan infrastruktur air bersih sangat penting terhadap perbaikan kualitas hidup manusia yang berkaitan dengan tingkat kemiskinan.

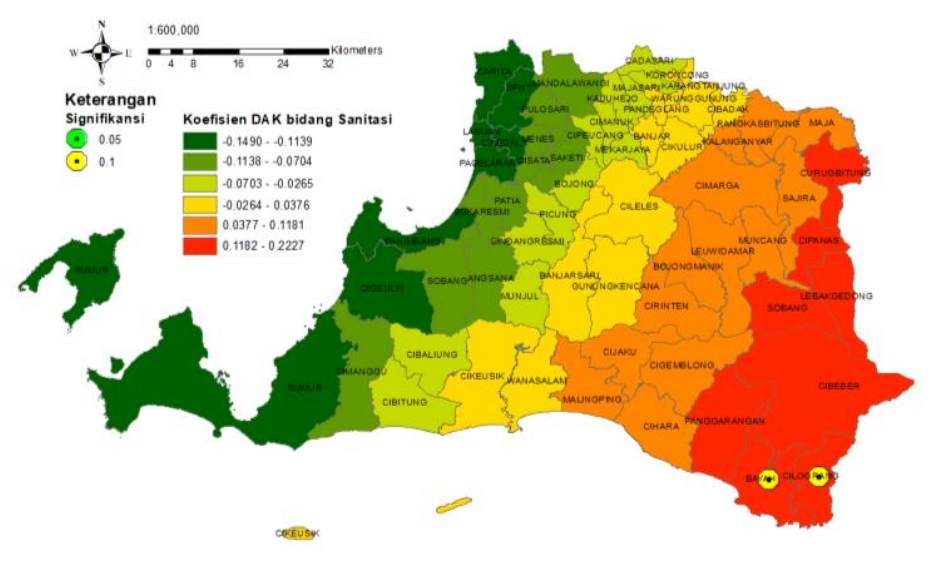

Gambar 10. Koefisien Pengaruh DAK Bidang Sanitasi terhadap Kemiskinan

\section{Pengaruh DAK Bidang Pasar Terhadap Kemiskinan}

Hasil analisis terhadap koefisien GWR (Gambar 11) dapat diketahui bahwa DAK bidang pasar berpengaruh negatif terhadap kemiskinan di semua wilayah amatan serta berpengaruh signifikan di 28 kecamatan. Hal ini menunjukkan bahwa alokasi DAK bidang pasar mempengaruhi dalam menurunkan angka kemiskinan baik di Kabupaten Lebak maupun Kabupaten Pandeglang. Hal tersebut menunjukkan semakin mudahnya akses terhadap pasar maka akan semakin mudah terhadap pemenuhan kebutuhan dasar masyarakat terutama akses pangan sehingga akan berimbas terhadap kesejahteraan masyarakat. Berdasarkan hasil penelitian Putra \& Yasa (2017) menunjukkan bahwa program revitalisasi pasar memberikan hasil yang signifikan dan berdampak positif terhadap peningkatan jumlah kunjungan, peningkatan pendapatan pasar dan peningkatan pendapatan pedagang.

\section{Pengaruh Dana Desa Terhadap Kemiskinan}

Salah satu prioritas dana desa adalah pembangunan desa yang bertujuan untuk meningkatkan kesejahteraan masyarakat desa dan penanggulangan kemiskinan melalui pemenuhan kebutuhan dasar, pembangunan sarana dan prasarana desa, pengembangan potensi lokal serta pemanfaatan sumber daya alam dan lingkungan secara berkelanjutan. Dari hasil permodelan (Gambar 12) dapat diketahui bahwa alokasi Dana Desa menunjukkan kecenderungan dalam menurunkan angka kemiskinan di sebagian besar wilayah/kecamatan di Kabupaten Pandeglang dan Lebak (warna hijau sampai kuning tua). Hal tersebut menunjukkan bahwa Dana Desa berpengaruh dalam menurunkan angka kemiskinan walaupun dari uji signifikansi belum menunjukkan pengaruh yang nyata. Dengan adanya anggaran yang diberikan langsung kepada desa, desa dapat memprioritaskan pembangunan desa terutama infrastruktur desa serta pemberdayaan 


\section{Analisis Pengaruh Alokasi DAK Masing-Masing Bidang Terhadap Tingkat Kemiskinan ...}

masyarakat sehingga dapat mendorong kegiatan ekonomi dan dapat meningkatkan kapasitas masyarakat desa dalam pengembangan wirausaha. Hasil penelitian ini sejalan dengan penelitian Artino et al. (2017) bahwa ada kecenderungan dana desa dapat mengurangi kemiskinan di semua desa di Kabupaten Lombok Utara, meskipun secara statistika menunjukkan hasil yang belum signifikan. Begitu pula dengan hasil penelitian Hasibuan et al. (2019) yang menunjukkan bahwa dana desa memiliki pengaruh yang beragam di Kabupaten Bandung Barat, dimana dana desa di bidang penyelenggaraan pemerintah tidak berpengaruh dalam menurunkan kemiskinan, sedangkan dana desa di bidang pembangunan fisik dan bidang pemberdayaan masyarakat menunjukkan pengaruh dalam menurunkan angka kemiskinan.

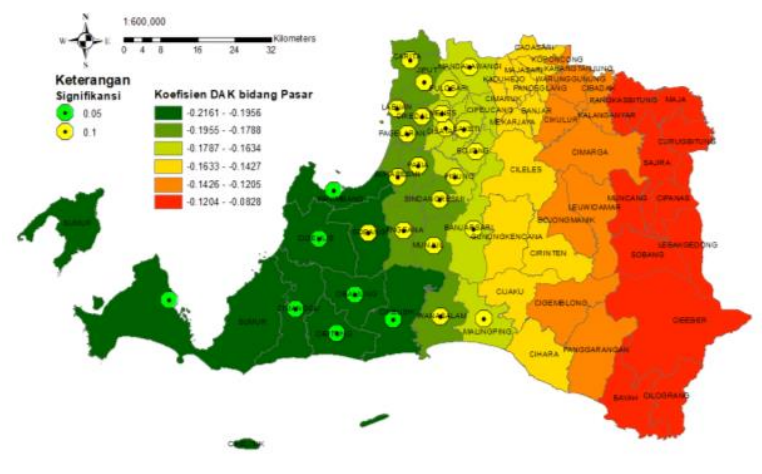

(a)

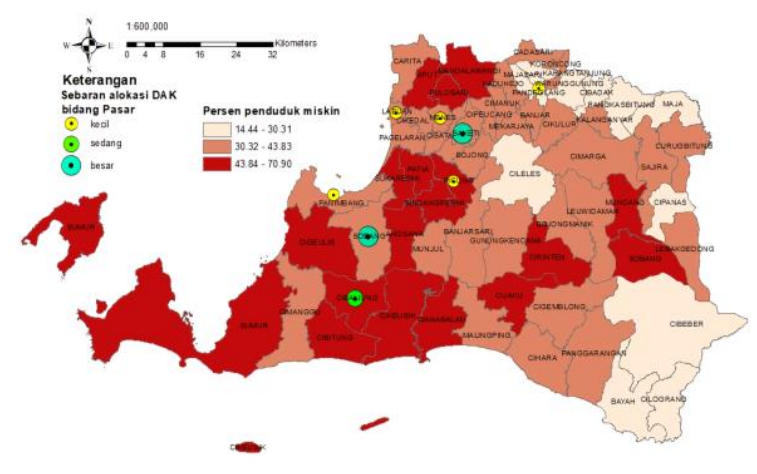

(b)

Gambar 11. Pengaruh DAK Bidang Pasar terhadap Kemiskinan (a) Koefisien dan (b) Sebaran Alokasi DAK dan Persentase Penduduk Miskin

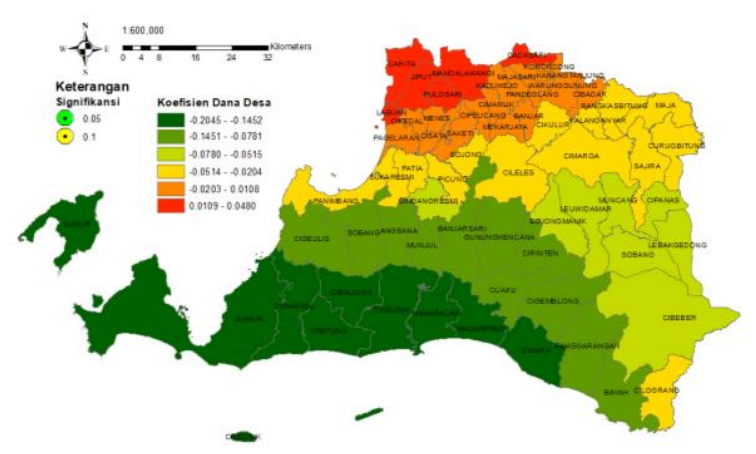

(a)

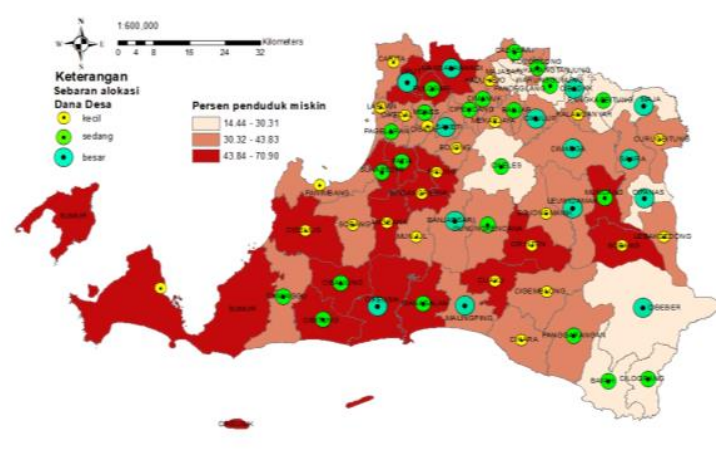

(b)

\section{Gambar 12. Pengaruh Dana Desa terhadap Kemiskinan (a) Koefisien dan (b) Sebaran Alokasi DAK dan Persentase Penduduk Miskin}

\section{Pengaruh Kepadatan Penduduk Terhadap Kemiskinan}

Secara teori jumlah penduduk memiliki pengaruh yang positif terhadap tingkat kemiskinan, yang berarti semakin banyak jumlah penduduk suatu wilayah maka akan semakin tinggi tingkat kemiskinan wilayah tersebut. Akan tetapi hasil penelitian ini menunjukkan hal yang sebaliknya, koefisien kepadatan penduduk di semua wilayah baik di Kabupaten Lebak maupun Pandeglang menunjukkan hasil yang negatif dan beragam. Adapun angka koefisien kepadatan penduduk bernilai negatif dengan rentang -0,4927 
sampai -0,2592 (Gambar 13). Berdasarkan data kepadatan penduduk, dapat diketahui bahwa beberapa kecamatan dengan kepadatan penduduk relatif rendah dibandingkan dengan kecamatan lain justru merupakan kecamatan dengan persentase penduduk miskin yang cukup tinggi. Tingginya tingkat kemiskinan dengan kepadatan penduduk yang rendah di beberapa wilayah Kabupaten Pandeglang, selain kecamatan tersebut merupakan kantong-kantong kemiskinan, wilayah tersebut merupakan wilayah dengan tingkat pendidikan yang relatif rendah. Berdasarkan penelitian Jumiati et al. (2019) yang menunjukkan bahwa pada tahun 2016 jumlah total warga buta aksara di Kabupaten Pandeglang relatif tinggi dan paling banyak di daerah selatan yaitu Kecamatan Sumur, Cimanggu, Cibitung, Cibaliung dan sekitarnya. Kepadatan penduduk berpengaruh negatif terhadap kemiskinan dapat disebabkan oleh kepadatan penduduk yang tinggi dapat mendorong aktivitas ekonomi yang tinggi pula sehingga dapat mendorong pertumbuhan ekonomi di wilayah tersebut, hal ini dapat dilihat dari daerah-daerah dengan kepadatan penduduk yang tinggi yang merupakan pusat ibukota dan pusat perekonomian di kedua kabupaten. Latuconsina (2017) menjelaskan penduduk yang padat mengakibatkan terkonsentrasinya kegiatan-kegiatan ekonomi serta jangkauan pelayanan infrastruktur menjadi lebih efisien.

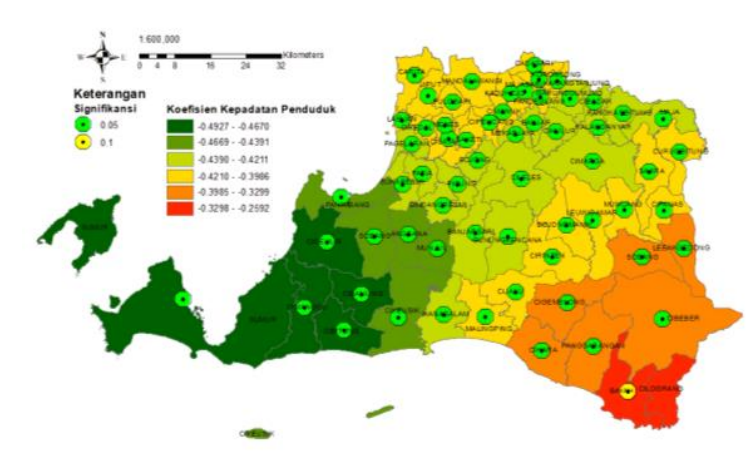

(a)

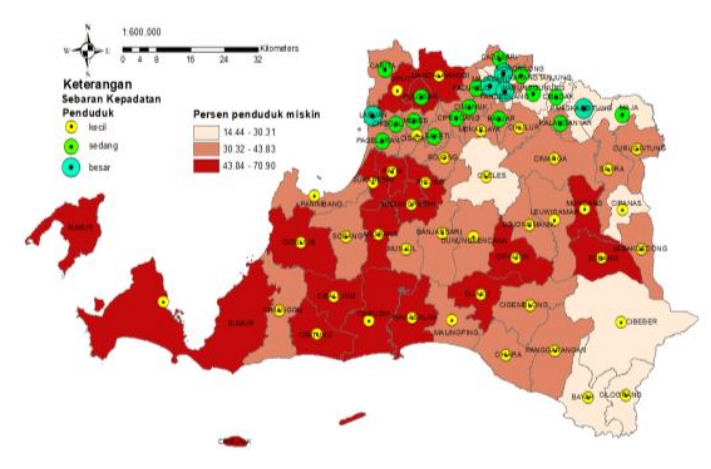

(b)

Gambar 13. Pengaruh Kepadatan Penduduk terhadap Kemiskinan (a) Koefisien dan (b) Kepadatan Penduduk dan Persentase Penduduk Miskin

\section{Kesimpulan}

Berdasarkan hasil estimasi GWR secara spasial DAK masing-masing bidang, dana desa dan kepadatan penduduk menunjukkan pengaruh yang berbeda di setiap kecamatan. Secara umum, variabel DAK masing-masing bidang cenderung untuk menurunkan kemiskinan di wilayah Kabupaten Pandeglang dan Lebak. Berdasarkan hal tersebut, maka program pengentasan kemiskinan di tiap kecamatan disesuaikan dengan masing-masing bidang dari DAK yang berpengaruh sehingga akan jauh lebih efisien. Berdasarkah dari hasil penelitian, perlu optimalisasi anggaran DAK bidang pertanian dan bersinergi dengan anggaran dana desa terutama untuk sektor pertanian yang merupakan salah satu leading sector baik di Kabupaten Pandeglang maupun Kabupaten Lebak. Selain itu perlu adanya peningkatan alokasi DAK terutama terkait infrastruktur seperti jalan dan pasar sehingga memudahkan aksesibilitas terhadap pelayanan publik serta optimalisasi alokasi DAK bidang air minum dan sanitasi di wilayah dengan tingkat kemiskinan tinggi terutama Kabupaten Pandeglang. Hasil penelitian ini diharapkan dapat dijadikan pertimbangan bagi pemerintah daerah dalam menentukan kebijakan pengentasan kemiskinan yang berbasis wilayah/kecamatan terutama dalam pengalokasian anggaran DAK masing-masing bidang 


\section{Analisis Pengaruh Alokasi DAK Masing-Masing Bidang Terhadap Tingkat Kemiskinan ...}

sehingga akan sesuai dengan kebutuhan dan prioritas masing-masing wilayah serta akan lebih tepat sasaran.

\section{Daftar Pustaka}

Artino, A., Juanda, B., \& Mulatsih, S. (2017). Keterkaitan dana desa terhadap kemiskinan di Kabupaten Lombok Utara. Institut Pertanian Bogor.

Azwardi. (2014). Pengaruh pengeluaran pemerintah provinsi di Indonesia untuk fungsi ekonomi, kesehatan, pendidikan serta perumahan dan fasilitas umum terhadap penduduk miskin tahun 2011-2013. Jurnal Ekonomi Pembangunan, 12(1), 1-11. doi:10.29259/jep.v12i1.4862.

Bappenas. (2011). Analisis perspektif, permasalahan dan dampak dana alokasi khusus (DAK). Jakarta.

Chen, K. M., \& Wang, T. M. (2015). Determinants of poverty status in Taiwan: A multilevel approach. Social Indicators Research, 123(2), 371-389. doi:10.1007/s11205-014-0741-4.

Djata, B. T. (2018). Peran pendamping serta dampak anggaran di bidang kelautan dan perikanan terhadap kondisi kesejahteraan masyarakat nelayan di Kabupaten Ende. Jurnal Perilaku dan Strategi Bisnis, 6(1), 78-102. doi:10.26486/jpsb.v6i1.

Fan, S., Zhang, X., \& Rao, N. (2004). Public expenditure, growth and poverty reduction in rural Uganda. Development Strategy and Governance Division (DSDG) Discussion Paper. Washington DC: International Food Policy Research Institute.

Fotheringham, A., Brunsdon, C., \& Charlton, M. (2002). Geographically weighted regression: the analysis of spatially varying relationships. New Jersey: John Wiley \& Sons.

Hasanah, H., \& Siregar, H. (2014). Pengaruh belanja pemerintah daerah untuk kesejahteraan rakyat terhadap penurunan kemiskinan di Indonesia: Analisis ekonometrika panel data tingkat provinsi. Prosiding Seminar Nasional \& Sidang Pleno ISEI XVII, 255-264.

Hasibuan, S. N., Juanda, B., \& Mulatsih, S. (2019). Efektivitas penggunaan dana desa dalam menurunkan kemiskinan di Kabupaten Bandung Barat. Institut Pertanian Bogor.

Herawati, A. R., \& Ginting, K. R. (2019). Analysis of the special economic zone in Tanjung Lesung on sustainable tourism. Collaborative Governance dalam Pengembangan Pariwisata di Indonesia, 1(1), 4253. Jakarta: STIA LAN Jakarta.

Hermawan, I. (2012). Analisis eksistensi sektor pertanian terhadap pengurangan kemiskinan di pedesaan dan perkotaan. MIMBAR, Jurnal Sosial dan Pembangunan, 28(2), 135-144. doi:10.29313/mimbar.v28i2.348.

Jolianis. (2016). Analisis pengaruh PAD, DAU, DAK terhadap kemiskinan pada Kabupaten/Kota di Provinsi Sumatera Barat dengan pertumbuhan ekonomi sebagai variabel intervening. Economica: Journal of Economic and Economic Education, 4(2), 192-209. doi:10.22202/economica.2016.v4.i2.633.

Juanda, B, \& Handra, H. (2017). Reformasi mekanisme dana alokasi khusus (DAK) untuk mendorong pertumbuhan dan pemerataan pembangunan di Indonesia. Jakarta.

Juanda, B, Paddu, A. H., Robiani, B., \& Kaiwai, H. Z. (2014). Kajian atas indikator standar pelayanan nasional di bidang layanan publik dasar yang relevan dengan pengalokasian dana alokasi khusus. Jakarta.

Jumiati, I. E., Budiati, A., Handayani, R., \& Rahmawati. (2019). Solusi strategis kemiskinan Kabupaten Pandeglang Provinsi Banten. Journal of Indonesian Public Administration and Governance Studies (JIPAGS), 3(2), 656-670. doi:10.31506/jipags.v3i2.7554.

Krisnawati, E., Suman, A., \& Saputra, P. M. A. (2018). Kajian pengaruh program nasional upaya khusus peningkatan produksi padi terhadap kemiskinan perdesaan di Wilayah Barat dan Timur Indonesia. Jurnal Ilmu Ekonomi dan Pembangunan (JIEP), 18(1), 14-33. doi:10.20961/jiep.v18i1.17550.

Latuconsina, Z. M. Y. (2017). Analisis faktor-faktor yang mempengaruhi indeks pembangunan manusia Kabupaten Malang berbasis pendekatan perwilayahan dan regresi panel. Journal of Regional and Rural Development Planning, 1(2), 202-216. doi:10.29244/jp2wd.2017.1.2.202-216.

Lenz, L., Munyehirwe, A., Peters, J., \& Sievert, M. (2015). Does large scale infrastructure investment alleviate poverty? impacts of Rwanda's electricity access roll-out program. Leibniz-Institut für Wirtschaftsforschung, Ruhr-University Bochum, TU Dortmund University, University of Duisburg-Essen.

Martinez-Aguilar, S., Fuchs, A., Ortiz-Juarez, E., \& Del Carmen, G. (2017). The impact of fiscal policy on 
inequality and poverty in Chile (No. WPS 7939). Washington DC. Retrieved from https://openknowledge.worldbank.org/handle/10986/25948.

Panji, I. P. B., \& Indrajaya, I. G. B. (2016). Pengaruh dana perimbangan terhadap pertumbuhan ekonomi dan tingkat kemiskinan di Provinsi Bali. E-Journal Ekonomi Pembangunan Universitas Udayana, 5(3), 316384.

Putra, I. K. D. P., \& Yasa, I. G. W. M. (2017). Efektivitas dan dampak revitalisasi pasar tradisional terhadap jumlah kunjungan, pendapatan pedagang dan pendapatan pasar di Kota Denpasar. E-Journal Ekonomi Pembangunan Universitas Udayana, 6(9), 1737-1768.

Qomariyah, N., Suharno, S., \& Priyarsono, D. S. (2017). Dampak transfer fiskal (conditional grant) terhadap pembangunan pertanian, kemiskinan dan ketimpangan di Indonesia: Analisis data panel. Agriekonomika, 6(2), 164-173. doi:10.21107/agriekonomika.v6i2.1874.

Sukanto, S., Juanda, B., Fauzi, A., \& Mulatsih, S. (2018). Dampak dana transfer dan peran kelembangaan terhadap kinerja pembangunan di Provinsi Banten. Institut Pertanian Bogor.

Syamsuri, M. R., \& Bandiyono, A. (2018). Pengaruh belanja pemerintah daerah berdasarkan fungsi terhadap peningkatan IPM dan pengentasan kemiskinan (studi pada Kabupaten/Kota di Provinsi Aceh). Info Artha, 2(1), 11-28. doi:10.31092/jia.v2i1.235.

Yudha, E. P., Juanda, B., Kolopaking, M. L., \& Kinseng, R. A. (2018). Implementasi pengelolaan keuangan desa dan pengaruhnya terhadap kinerja pembangunan perdesaan (studi kasus Kabupaten Pandeglang Banten). Institut Pertanian Bogor. 